\title{
Possible therapeutic implication of PD-L1/ PD-1 axis in endometrial cancer
}

\author{
Jiezhong Chen ${ }^{1}$, Renfu Shao ${ }^{2}$, Chen Chen ${ }^{1}$ \\ 1. School of Biomedical Sciences, University of Queensland, St Lucia, Australia. 2. GeneCology Research Centre, Faculty \\ of Science, Health, Education and Engineering, University of the Sunshine Coast, Maroochydore, Australia.
}

Correspondence: Dr. Jiezhong Chen or Professor Chen Chen. Address: School of Biomedical Sciences, University of Queensland, St Lucia, QLD 4072, Australia. Email: j.chen4@uq.edu.au or chen.chen@uq.edu.au

Received: November 28, 2014

Accepted: December 29, 2014

Online Published: January 27, 2015

DOI : $10.5430 /$ jst.v5n1p10

URL: http://dx.doi.org/10.5430/jst.v5n1p10

\section{Abstract}

Endometrial cancer (EC) is a common reproductive system cancer in females and one of the leading causes for cancer-related deaths in women, ranked only after ovarian and cervical cancers. It is classified into two types with type I having better prognosis. At present, surgical removal is the major approach for the treatment of the disease. For those with metastasized cancer, chemotherapy, hormone therapy and radiotherapy are applied. However, the therapeutic efficacy is unsatisfactory and toxicity is severe. Recently, immune system has been recognized as an important factor in both cancer development and treatment. Immunotherapy against PD-1 has been shown to be effective with low side-effects in many cancers. This opens a novel approach for EC treatment as EC has been shown to have increased PD-L1/PD-1 axis. In this review, we summarize the most recent progress in PD-L1/PD-1 axis and prospect that anti PD-L1/PD-1 may be an effective approach for EC treatment.

\section{Key words}

Immune escape ability, IFN-gamma, Hypoxia, Shp2/PTEN/PI3K/Akt pathway

\section{Introduction}

Endometrial cancer (EC) is a common reproductive system cancer in females ${ }^{[1]}$. EC incidence was estimated to be 32,000 worldwide in 2012 and caused 76,000 deaths in the same year ${ }^{[2]}$. The common risk factors associated with EC are obesity, diabetes, high blood pressure and excessive estrogen exposure ${ }^{[3-6]}$. EC incidence is increasing every year in parallel to the increase of obese population ${ }^{[6]}$. The treatment outcomes of EC depend on cancer types or grades. EC is classified into two types with type I having better prognosis ${ }^{[7]}$. Type I ECs are low grade endometrioid adenocarcinomas, which are sensitive to hormone therapy as these cancers express both estrogen receptor (ER) and progesterone receptor (PR) ${ }^{[7]}$. The 5 -year survival rate of type I ECs is more than $80 \%{ }^{[8]}$. Type II ECs include high grades of endometrioid adenocarcinoma, serous papillary and clear-cell cancers ${ }^{[9]}$. Type II ECs are not sensitive to estrogen and progesterone. Type II ECs are poorly differentiated and highly aggressive, resulting in a 5 year survival rate less than $35 \%^{[10-13]}$. Molecular characteristics of high-grade ECs are different from that of low-grade ECs. For example, serous papillary EC has frequent TP53 mutations and decreased ER and PR expression while type I ECs usually have frequent mutations in PTEN, PIK3CA, ARIDIA, Kras and beta-catenin ${ }^{[14,15]}$. At present, surgical removal is the main approach for the treatment of ECs in the early stage with high survival rate for low-grade and unmetstasized tumours ${ }^{[16-18]}$. For those with metastasized cancer, chemotherapy, 
hormone therapy and radiotherapy are applied. The therapeutic outcomes, however, are unsatisfactory and toxicity is severe. Thus, new approach is needed to increase treatment efficacy of EC.

Recently, the importance of cancerous immune system is highly recognized. The lack of immunological control is considered as a hallmark for cancer development, i.e. cancer cells are able to evade human immune system during tumour formation ${ }^{[19]}$. Effective immune system is also necessary for cancer therapy to eliminate cancer cells weakened by chemotherapy or targeted therapy. Thus stimulation of immune system (immunotherapy) has been studied to increase treatment efficacy for EC. There are two types of immune therapies; vaccination and immune checkpoint blockage ${ }^{[20]}$. Vaccination is based on genetic and epigenetic alterations in cancers, which provide a diverse set of antigens for inducing anti-tumour immunity. At present, sipuleucel-T $\left(\right.$ Provenge $^{\circledR}$ ), which are dendritic cells stimulated by antigen prostatic acid phosphatase, was approved by the Food and Drug Administration for the treatment of metastatic hormone-refractory prostate cancer ${ }^{[21]}$. However, the effectiveness of vaccination could be reduced by cancer immune escape ability. Cancer can stimulate the inhibition system of immune cells. For example, activation of T-cells requires that antigens are presented by antigen presenting cells (APC) through major histocompatibility complex (MHC) and activation of co-receptor CD28 by cytokines. The activation of T-cells is fine-tuned by inhibition signals through cytotoxic T-lymphocyte-associated protein 4 (CTLA4) or programmed death-1 (PD-1) ${ }^{[20]}$. Cancer cells can express PD-1 ligand PD-L1 to enhance the inhibition of T-cells. Thus, immunotherapy has been developed to reduce PD-1 to stimulate patients' own immune system and has been shown to be effective with low side-effects in many cancers ${ }^{[22-26]}$. In melanoma, inhibition of PD-L1/PD-1 caused sustainable tumour-shrinkage effect in 31\% patients and was proposed to be used together with targeted therapy

against MAPK pathway ${ }^{[26,27]}$. The approach also caused $29 \%$ and $17 \%$ response rate in kidney and lung cancers, respectively ${ }^{[28-30]}$.

Immunotherapy has also been explored in papillary serous EC patients by using patients' dendritic cells which are treated with tumour lysates. The major problem of this method is immunosuppression from cancer cells ${ }^{[31]}$. Inhibition of PD-L1/PD-1 axis has never been tested in EC. Recent studies show that this axis is increased in $\mathrm{EC}^{[32,33]}$. This raises a possibility for the treatment of endometrial cancer through inhibition of PD-L1/PD-1 axis. In this review, we summarize the most recent progress in PD-L1/PD-1 axis research and discuss the possible integration of this new approach into EC treatment regime such as combination with chemotherapy, hormone therapy and targeted therapy.

\section{PD-L1/ PD-1 axis in immune responses}

PD-1 was discovered as an immune modulator in 1992, which negatively regulates lymphocyte activity so that the cytotoxic effects of T-cells on self-tissues can be avoided ${ }^{[34]}$. PD-1 is a 50-55 kDa glycoprotein containing a stalk, a transmembrane domain and an intracellular domain (see Figure 1). PD-1 expresses in many cells including CD4+ and CD8+ T-Cells, B-cells, natural killer cells, macrophages and dendritic cells, indicating its extensive roles in the immune system. PD-1 is able to suppress T-cell proliferation and function to balance activation status, which is stimulated by recognization of antigens through MHC together with co-stimulatory molecules such as CD28 ${ }^{[35]}$. Loss of PD-1 can lead to over-activation of T-cells and autoimmune diseases. In mice, knockout of PD-1 caused several autoimmune diseases including systemic lupus erythematosus, psoriasis and dilated cardiomyopathy ${ }^{[36,37]}$. Blockage of PD-1 by anti-PD-1 antibody in vivo has also been shown to increase experimental autoimmune encephalomyelitis in mice ${ }^{[38]}$.

Two PD-1 ligands are identified including PD-L1 and PD-L2 ${ }^{[35,39]}$. PD-L1 and PD-L2 have similar structure but different expression patterns and kinetics. PD-L1 expresses in all cell types and many cancer cells. PD-L2 is only expressed by activated T cells, myeloid dendritic cells and macrophages ${ }^{[40]}$. Therefore, PD-L1 is more related to cancer immune escape ability. PD-L1 is regulated by many inflammatory factors including IFN-gamma, LPS, GM-CSF, IL-4 and IL-10 through signalling pathways such as MEK and JAK2 ${ }^{[41]}$. 
The mechanisms for the inhibitory role of PD-1 in T-cells has been extensively studied. Alterations of signalling pathways by PD-1 are initiated by phosphorylation of SHP-2, which in turn cause phosphorylation of PTEN and decreased PI3K activity ${ }^{[42]}$. PI3K/Akt plays an important role in T-cell survival, proliferation, migration and function (see Figure 1) ${ }^{[43]}$. Via Akt PD-1 can decrease the expression of mitochondrial anti-apoptotic molecule Bcl-xL, leading to T-cell apoptosis ${ }^{[44,45]}$. Akt downstream target protein mTOR levels are reduced by PD-1, leading to decreased cell size. Cell proliferation is also decreased due to decreased expression of cyclin D and c-myc ${ }^{[46]}$. PD-1 subunits have been associated with Src members Lck and Lyn ${ }^{[47,48]}$. But it is not well studied how these kinases are involved in the regulation of T- and B- cells by PD-1. The inhibitory effect of PD-1 on T-cells can be overcome by co-stimulator CD28 and IL-2, suggesting a regulation balance in activation and inhibition ${ }^{[49]}$.

Figure 1. Negative regulation of PD-1 on lymphocytes.

Note. TCR can activate PI3K/Akt pathway to promote T-cell survival, proliferation, cell growth and CTL ability. PD-1 increases SHP-2 phosphorylation which in turn phosphorylates PTEN, leading to a decrease in PI3K activity.

Abbreviation: TCR: T-cell receptor; PI3K: Phosphatidylinositol-4,5-bisphosphate 3-kinase; Akt: protein kinase B; PTEN: Phosphatase and tensin homolog; CTL: Cytotoxic T Lymphocytes.

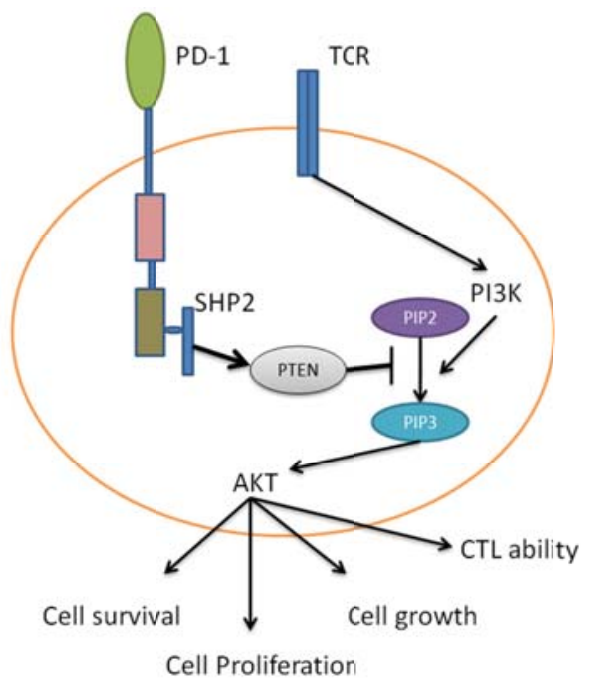

Except expression on cell surface, there are many soluble forms of PD- 1 caused by RNA splicing ${ }^{[35,50,51]}$. PD- 1 is encoded by several exons. Splicing of RNAs results in various PD-1s including several soluble forms ${ }^{[51]}$. Soluble PD-1 (sPD-1) has been involved in regulation of PD-L1/PD-1 axis. SPD-1 containing exon-2 can bind to PD-L1, leading to disruption of PD-L1/PD-1 interaction and thus reducing PD-1 inhibitory effect on T-cells.

\section{Expression of PD-L1 in EC}

The expression of PD-L1 in ECs has been studied. Vanderstraeten et al assessed the expression of PD-L1, PDL2 in EC patient samples ${ }^{[32]}$. PD-L1 was found at high levels in 92\% of ECs while PD-L2 expressed at very low levels in these tumors. In this study, other immune related molecules including B7-H4, indoleamine 2,3-dioxygenase (IDO), galectin1, galectin-3 and arginase-1 were also examined. B7-H4, which also negatively regulates T-cells, was expressed in $90 \%$ of $\mathrm{ECs}^{[32,52]}$. However, IDO was only expressed in $21 \%$ of ECs and expression of glectin- 1 and 3 in tumor lysates was not different from benign tissues. Overall, this study suggested that the PD-L1/PD-1 interaction and B7-H4 might be important for ECs to escape from immune responses and could be targets for inhibition for treating EC patients.

EC has been shown to be associated with inflammatory status ${ }^{[53]}$. Increased CD8 can increase IFN-gamma which can stimulate PD-L1 ${ }^{[54]}$. It has been shown that serous papillary EC has IFN-gamma receptor and thus PD-L1 is stimulated in these cells ${ }^{[33]}$. The mechanism is mediated by Stat ${ }^{[33]}$. Indeed, Stat 1 is highly elevated in serous papillary EC cells. Stat1 can also up-regulate other genes to increase EC proliferation and metastasis. Another study showed that IFN-gamma increased PD-L1 expression via another signalling pathway PKD2, suggesting multiple signalling pathways are involved in regulation of PD-L1 (see Figure 2) ${ }^{[55]}$. 
Hypoxia status is a major feature of cancer. It has been shown that hypoxia upregulates PD-L1 via HIF-1 $\alpha$ but not HIF $-2 \alpha^{[56]}$. Barsoum et al showed that hypoxia for 24 hours resulted in an increase in HIF-1 $\alpha$ and PD-L1 in human MDA-MB-231 breast cancer cells, human DU145 prostatic carcinoma cells, human Jurkat leukemia T cells and mouse B16-F10 melanoma and 4T1 mammary carcinoma cells ${ }^{[57]}$. Glyceryl trinitrate (GTN), an agonist of nitric oxide (NO), which is a blocker of HIF-1 $\alpha$ accumulation in hypoxic cells, prevented hypoxia-induced PD-L1 expression. Therefore, HIF- $1 \alpha$ is a major mediator of hypoxia-induced induction of PD-L1 (see Figure 2) ${ }^{[57]}$. PD-L1 induced T cell apoptosis was blocked by disruption of PD-L1/PD-1 interaction. This is applicable in EC which associated with hypoxia ${ }^{[58-60]}$. For example, EC is highly associated with obesity which induces hypoxia ${ }^{[61]}$. Obesity-induced hypoxia in microenvironments of tumour has been well documented ${ }^{[62,63]}$. However, whether this is linked to PD-L1 increase is not studied.

Figure 2. Increased expression of PD-L1 in endometrial cancer cells

IFN-gamma increases PD-L1 via Stat1 and PKD2. Hypoxia upregulates PD-L1 via HIF-1 $\alpha$. Abbreviations: IFN-gamma; interferon gamma, PKD2; protein kinase D isoform 2, Stat1; Signal transducer and transcription activator, HIF-1 $\alpha$; hypoxia-induced factor $1 \alpha$.

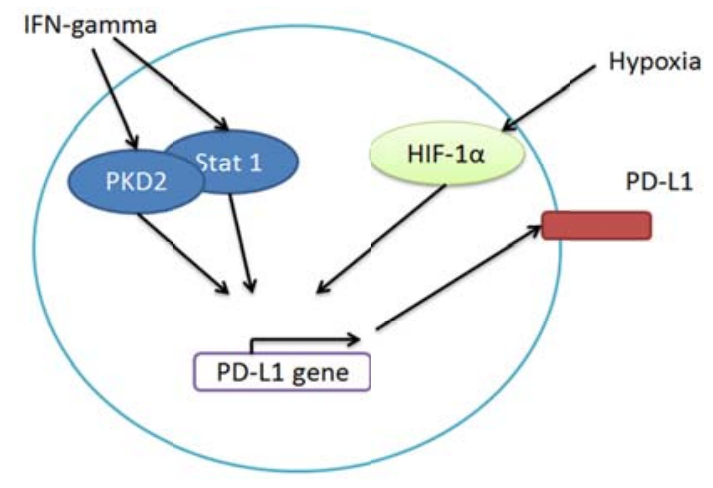

\section{Therapeutic implications}

As PD-L1/PD-1 axis may play a key role in immune suppression in endometrial cancer, inhibition of this axis could be effective in increasing immune responses against cancer cells. Three approaches may be applied to achieve suppression of PD-L1/PD-1 axis including using anti-PD-1 or anti-PD-L1 antibodies, RNA interference against PD-1 or PD-L1 and supplementation of soluble PD-1.

Anti-PD-1 antibodies include Nivolumab, Pembrolizumab and Pidilizumab. Anti-PD-L1 antibodies are BMS-936559, MPDL3280A and MEDI-4736. These antibodies have been used in clinical trials and showed effectiveness and low toxicities in several solid tumours ${ }^{[64]}$. Therefore, it is possible to use them for the treatment of ECs. The advantage for the application of these antibodies in ECs is topical usage, which may increase treatment efficacy.

RNA interference has been used to knock out important genes for the treatment of cancer. This method has also been applied for manipulation of PD-1/PD-L1 axis. Li et al (2012) used siRNA to silence PD-L1 and demonstrated that it decreased cancer cell growth in lymphoma ${ }^{[65]}$. Iwamura et al (2011) showed siRNA effect in lung cancer cell line ${ }^{[66]}$. Borkner et al (2010) used siRNA against PD-1 to increase CD8 function in melanoma cells ${ }^{[67]}$.

In addition, soluble PD-1 may be used to dilute PD-L1 thus block the interaction of increased PD-L1 with PD-1 on lymphocytes. Over-expression of sPD-1 or sPD-L1 has been shown to increase cell immunity against cancer cells ${ }^{[68]}$. Song et al (2011) used sPD-1 DNA to enhance CD8 T-cells and DC cells ${ }^{[69]}$. Qiu et al (2009) used sPD-1 peptide to increase anti-tumour activity ${ }^{[70]}$. sPD-1 is also effective in hepatoma ${ }^{[71,72]}$.

\section{Combination therapy}

Combination of anti-PD-L1/PD-1 and other common therapies in ECs increases treatment efficacy and reduces side-effects reduction. Common chemotherapeutic agents used in ECs included paclitaxel, doxorubicin and carbop- 
latin ${ }^{[73]}$. High-dose of the administration of these drugs has been shown to increase patient survival rate ${ }^{[73]}$. These drugs, however, cause side-effects including hair loss, low neutrophil levels and gastrointestinal problems. Combination of chemotherapy with anti-PD-L1/PD-1 may reduce the dosage of these drugs and thus decrease side-effects.

Many signalling pathways have been shown to be increased in endometrial cancer such as PI3K and Wnt, VEGF and EGFR ${ }^{[74-77]}$. These signalling pathways promote cell proliferation and decrease apoptosis and thus are important for cancer maintenance and progression. Activation of signalling pathways could be caused by hormones, viruses and gene mutations ${ }^{[78-82]}$. Inhibitors have been developed to target key molecules in these pathways for the treatment of EC. Among them, PI3K/Akt pathway is the most studied pathway ${ }^{[77]}$. Akt can regulate mitochondrial apoptotic pathway to increase EC cell survival and proliferation. Akt down-stream mitochondrial anti-apoptotic protein Bcl-2 is increased in ECs and correlated with disease stages ${ }^{[83]}$. Cisplatin-induced Bcl-2 increase through Akt activation is associated with drug resistance ${ }^{[84]}$. Dual PI3K/mTOR inhibitor GDC-0941 and mTOR inhibitor (temsirolimus) are effective to EC cell lines with PIK3CA or PTEN mutations ${ }^{[85]}$. It is possible to combine targeted therapy with anti-PD-L1/PD-1 therapy. Cancer cells weakened by targeted therapy could be eliminated further by activated T-cells.

\section{Conclusions}

PD-L1/PD-1 inhibition is effective in many cancers and has been in Phase III clinical trials. Recent studies showed that PD-L1 is also increased in endometrial cancer. This raises an opportunity for the treatment of EC by manipulating this axis. Inhibition of PD-L1/PD-1 will lead to activation of immune cells, especially T-cells, which can produce cytotoxic effect on cancer cells. The anti-PD-L1 /PD-1 therapy may be combined with other therapies such as chemotherapy, targeted therapy, etc.

\section{References}

[1] Siegel, R., et al. Cancer treatment and survivorship statistics. CA Cancer J Clin. 2012; 62(4): 220-41.

[2] Stewart B, W.C., ed. World Cancer Report 2014. 2014

[3] Arem, H. and M.L. Irwin. Obesity and endometrial cancer survival: a systematic review. Int J Obes (Lond). 2012; 37(5): 634-9.

[4] Zaki, A., et al. Abdominal obesity and endometrial cancer in egyptian females with postmenopausal bleeding. Nutr Cancer. 2011; 63(8): 1272-8. PMid:22043928 http://dx.doi.org/10.1080/01635581.2011.615973

[5] Schmandt, R.E., et al. Understanding obesity and endometrial cancer risk: opportunities for prevention. Am J Obstet Gynecol. 2011; 205(6): 518-25. PMid:21802066 http://dx.doi.org/10.1016/j.ajog.2011.05.042

[6] Amant, F., et al. Endometrial cancer. The Lancet. 2005; 366(9484): 491-505. http://dx.doi.org/10.1016/S0140-6736(05)67063-8

[7] Fujimoto, T., et al. Endometrioid uterine cancer: histopathological risk factors of local and distant recurrence. Gynecologic oncology. 2009; 112(2): 342-347. PMid:19062082 http://dx.doi.org/10.1016/j.ygyno.2008.10.019

[8] Bokhman, J.V. Two pathogenetic types of endometrial carcinoma. Gynecologic oncology. 1983; 15(1): 10-17. http://dx.doi.org/10.1016/0090-8258(83)90111-7

[9] Lax, S.F., et al. Clear cell carcinoma of the endometrium is characterized by a distinctive profile of p53, Ki-67, estrogen, and progesterone receptor expression. Human pathology. 1998; 29(6): 551-558. http://dx.doi.org/10.1016/S0046-8177(98)80002-6

[10] Singh, P., et al. Serous carcinoma of the uterus - determination of HER-2/neu status using immunohistochemistry, chromogenic in situ hybridization, and quantitative polymerase chain reaction techniques: its significance and clinical correlation. International Journal of Gynecological Cancer. 2008; 18(6): 1344-1351. PMid:18248390 http://dx.doi.org/10.1111/j.1525-1438.2007.01181.x

[11] Alvarez, T., et al. Molecular profile of grade 3 endometrioid endometrial carcinoma: is it a type I or type II endometrial carcinoma? The American journal of surgical pathology. 2012; 36(5): 753-761. PMid:22498825 http://dx.doi.org/10.1097/PAS.0b013e318247b7bb

[12] Zorn, K.K., et al. Gene expression profiles of serous, endometrioid, and clear cell subtypes of ovarian and endometrial cancer. Clinical Cancer Research. 2005; 11(18): 6422-6430. PMid:16166416 http://dx.doi.org/10.1158/1078-0432.CCR-05-0508

[13] Moore, K.N. and A.N. Fader. Uterine papillary serous carcinoma. Clinical obstetrics and gynecology. 2011; 54(2): $278-291$. PMid:21508697 http://dx.doi.org/10.1097/GRF.0b013e318218c755 
[14] Network, C.G.A.R. Integrated genomic characterization of endometrial carcinoma. Nature. 2013; 497(7447): 67-73. PMid:23636398 http://dx.doi.org/10.1038/nature12113

[15] McConechy, M.K., et al. Use of mutation profiles to refine the classification of endometrial carcinomas. The Journal of pathology. 2012; 228(1): 20-30. PMid:22653804

[16] Creasman, W., et al. Carcinoma of the corpus uteri. International Journal of Gynecology \& Obstetrics. 2006; 95: S105-S143. http://dx.doi.org/10.1016/S0020-7292(06)60031-3

[17] Obermair, A., et al. Total laparoscopic hysterectomy versus total abdominal hysterectomy for obese women with endometrial cancer. International Journal of Gynecological Cancer. 2005; 15(2): 319-324. PMid:15823119 http://dx.doi.org/10.1111/j.1525-1438.2005.15223.x

[18] Cragun, J.M., et al. Retrospective analysis of selective lymphadenectomy in apparent early-stage endometrial cancer. Journal of Clinical Oncology. 2005; 23(16): 3668-3675. PMid:15738538 http://dx.doi.org/10.1200/JCO.2005.04.144

[19] Hanahan, D. and R.A. Weinberg, Hallmarks of cancer: the next generation. Cell. 2011; 144(5): 646-674. PMid:21376230 http://dx.doi.org/10.1016/j.cell.2011.02.013

[20] Kono, K. Current status of cancer immunotherapy. J Stem Cells Regen Med. 2014; 10(1): 8-13. PMid:25075156

[21] Kantoff, P.W., et al. Sipuleucel-T immunotherapy for castration-resistant prostate cancer. New England Journal of Medicine. 2010; 363(5): 411-422. PMid:20818862 http://dx.doi.org/10.1056/NEJMoa1001294

[22] Sznol, M. and L. Chen, Antagonist antibodies to PD-1 and B7-H1 (PD-L1) in the treatment of advanced human cancer. Clinical Cancer Research. 2013; 19(5): 1021-1034. PMid:23460533 http://dx.doi.org/10.1158/1078-0432.CCR-12-2063

[23] Afreen, S. and S. Dermime. The immunoinhibitory B7-H1 molecule as a potential target in cancer: Killing many birds with one stone. Hematology/oncology and stem cell therapy. 2014; 7(1): 1-17. PMid:24398144 http://dx.doi.org/10.1016/j.hemonc.2013.09.005

[24] Brahmer, J.R., et al. Safety and activity of anti-PD-L1 antibody in patients with advanced cancer. New England Journal of Medicine. 2012; 366(26): 2455-2465. PMid:22658128 http://dx.doi.org/10.1056/NEJMoa1200694

[25] Topalian, S.L., et al. Safety, activity, and immune correlates of anti-PD-1 antibody in cancer. New England Journal of Medicine. 2012; 366(26): 2443-2454. PMid:2265812 http://dx.doi.org/10.1056/NEJMoa1200690

[26] Hamid, O., et al. Safety and tumor responses with lambrolizumab (anti-PD-1) in melanoma. New England Journal of Medicine. 2013; 369(2): 134-144. PMid:23724846 http://dx.doi.org/10.1056/NEJMoa1305133

[27] Ott, P.A., F.S. Hodi, and C. Robert. CTLA-4 and PD-1/PD-L1 blockade: new immunotherapeutic modalities with durable clinical benefit in melanoma patients. Clinical Cancer Research. 2013; 19(19): 5300-5309. PMid:24089443 http://dx.doi.org/10.1158/1078-0432.CCR-13-0143

[28] Dong, H., et al. Tumor-associated B7-H1 promotes T-cell apoptosis: a potential mechanism of immune evasion. Nature medicine. 2002; 8(8): 793-800. PMid:12091876

[29] Harvey, R.D., Immunologic and Clinical Effects of Targeting PD-1 in Lung Cancer. Clinical Pharmacology \& Therapeutics. 2014; 96(2): 214-223. PMid:24690569 http://dx.doi.org/10.1038/clpt.2014.74

[30] Gunturi, A. and D.F. McDermott. Potential of New Therapies like Anti-PD1 in Kidney Cancer. Current treatment options in oncology. 2014; 15(1): 137-146. PMid:24504486 http://dx.doi.org/10.1007/s11864-013-0268-y

[31] Brooks, N. and D.S. Pouniotis. Immunomodulation in endometrial cancer. International Journal of Gynecological Cancer. 2009; 19(4): 734-740. PMid:19509580 http://dx.doi.org/10.1111/IGC.0b013e3181a12f7f

[32] Vanderstraeten, A., et al. Mapping the immunosuppressive environment in uterine tumors: implications for immunotherapy. Cancer Immunology, Immunotherapy. 2014; 63(6): 545-557. PMid:24658839 http://dx.doi.org/10.1007/s00262-014-1537-8

[33] Kharma, B., et al. STAT1 drives tumor progression in serous papillary endometrial cancer. Cancer research. 2014; 74(22): 6519-6530. PMid:25267067 http://dx.doi.org/10.1158/0008-5472.CAN-14-0847

[34] Ishida, Y., et al. Induced expression of PD-1, a novel member of the immunoglobulin gene superfamily, upon programmed cell death. The EMBO journal. 1992; 11(11): 3887. PMid:1396582

[35] Freeman, G.J., et al. Engagement of the PD-1 immunoinhibitory receptor by a novel B7 family member leads to negative regulation of lymphocyte activation. The Journal of experimental medicine. 2000; 192(7): 1027-1034. PMid:11015443 http://dx.doi.org/10.1084/jem.192.7.1027

[36] Okazaki, T. and J. Wang. PD-1/PD-L pathway and autoimmunity. Autoimmunity. 2005; 38(5): 353-357. PMid:16227150 http://dx.doi.org/10.1080/08916930500124072

[37] Okazaki, T. and T. Honjo. The PD-1-PD-L pathway in immunological tolerance. Trends in immunology. 2006; $27(4)$ : 195-201. PMid:16500147 http://dx.doi.org/10.1016/j.it.2006.02.001 
[38] Salama, A.D., et al., Critical role of the programmed death-1 (PD-1) pathway in regulation of experimental autoimmune encephalomyelitis. The Journal of experimental medicine. 2003; 198(1): 71-78. PMid:12847138 http://dx.doi.org/10.1084/jem.20022119

[39] Latchman, Y., et al. PD-L2 is a second ligand for PD-1 and inhibits T cell activation. Nature immunology. 2001; 2(3): 261-268. PMid:11224527 http://dx.doi.org/10.1038/85330

[40] Messal, N., et al. PD-L2 is expressed on activated human T cells and regulates their function. Molecular immunology. 2011; 48(15): 2214-2219. PMid:21752471 http://dx.doi.org/10.1016/j.molimm.2011.06.436

[41] Liu, J., et al. Plasma cells from multiple myeloma patients express B7-H1 (PD-L1) and increase expression after stimulation with IFN- $\gamma$ and TLR ligands via a MyD88-, TRAF6-, and MEK-dependent pathway. Blood. 2007; 110(1): 296-304. PMid:17363736 http://dx.doi.org/10.1182/blood-2006-10-051482

[42] Keir, M.E., et al. PD-1 and its ligands in tolerance and immunity. Annu. Rev. Immunol. 2008; 26: 677-704. PMid:18173375 http://dx.doi.org/10.1146/annurev.immunol.26.021607.090331

[43] Finlay, D. and D. Cantrell. Phosphoinositide 3-kinase and the mammalian target of rapamycin pathways control T cell migration. Annals of the New York Academy of Sciences. 2010; 1183(1): 149-157. PMid:20146713 http://dx.doi.org/10.1111/j.1749-6632.2009.05134.x

[44] Francisco, L.M., et al. PD-L1 regulates the development, maintenance, and function of induced regulatory T cells. The Journal of experimental medicine. 2009; 206(13): 3015-3029. PMid:20008522 http://dx.doi.org/10.1084/jem.20090847

[45] Chemnitz, J.M., et al. SHP-1 and SHP-2 associate with immunoreceptor tyrosine-based switch motif of programmed death 1 upon primary human T cell stimulation, but only receptor ligation prevents T cell activation. The Journal of Immunology. 2004; 173(2): 945-954. PMid:15240681 http://dx.doi.org/10.4049/jimmunol.173.2.945

[46] Shimatani, K., et al. PD-1+ memory phenotype CD4+ T cells expressing C/EBP $\alpha$ underlie T cell immunodepression in senescence and leukemia. Proceedings of the National Academy of Sciences. 2009; 106(37): 15807-15812. PMid:19805226 http://dx.doi.org/10.1073/pnas.0908805106

[47] Sheppard, K.-A., et al. PD-1 inhibits T-cell receptor induced phosphorylation of the ZAP70/CD3 $\zeta$ signalosome and downstream signaling to PKCO. FEBS letters. 2004; 574(1): 37-41. PMid:15358536 http://dx.doi.org/10.1016/j.febslet.2004.07.083

[48] Okazaki, T., et al. PD-1 immunoreceptor inhibits B cell receptor-mediated signaling by recruiting src homology 2-domaincontaining tyrosine phosphatase 2 to phosphotyrosine. Proceedings of the National Academy of Sciences. 2001; 98(24): 13866-13871. PMid:11698646 http://dx.doi.org/10.1073/pnas.231486598

[49] Carter, L.L., et al. PD-1: PD-L inhibitory pathway affects both CD4+ and CD8+ T cells and is overcome by IL-2. European journal of immunology. 2002; 32(3): 634-643. http://dx.doi.org/10.1002/1521-4141(200203)32:3<634::AID-IMMU634>3.0.CO;2-9

[50] Kuipers, H., et al. Contribution of the PD-1 ligands/PD-1 signaling pathway to dendritic cell-mediated CD4+ T cell activation. European journal of immunology. 2006; 36(9): 2472-2482. PMid:16917960 http://dx.doi.org/10.1002/eji.200635978

[51] Nielsen, C., et al. Alternative splice variants of the human PD-1 gene. Cellular immunology. 2005; 235(2): 109-116. PMid:16171790 http://dx.doi.org/10.1016/j.cellimm.2005.07.007

[52] Sica, G.L., et al. B7-H4, a molecule of the B7 family, negatively regulates T cell immunity. Immunity. 2003; $18(6)$ : 849-861. http://dx.doi.org/10.1016/S1074-7613(03)00152-3

[53] Maxwell, G.L., et al. Proteomic analysis of stage I endometrial cancer tissue: identification of proteins associated with oxidative processes and inflammation. Gynecologic oncology. 2011; 121(3): 586-594. PMid:21458040 http://dx.doi.org/10.1016/j.ygyno.2011.02.031

[54] Abiko, K., et al. PD-L1 on tumor cells is induced in ascites and promotes peritoneal dissemination of ovarian cancer through CTL dysfunction. Clinical Cancer Research. 2013; 19(6): 1363-1374. PMid:23340297

http://dx.doi.org/10.1158/1078-0432.CCR-12-2199

[55] Chen, J., et al. Interferon- $\gamma$-induced PD-L1 surface expression on human oral squamous carcinoma via PKD2 signal pathway. Immunobiology. 2012; 217(4): 385-393. PMid:22204817 http://dx.doi.org/10.1016/j.imbio.2011.10.016

[56] Noman, M.Z., et al. PD-L1 is a novel direct target of HIF-1 $\alpha$, and its blockade under hypoxia enhanced MDSC-mediated T cell activation. The Journal of experimental medicine. 2014: 5: 781-790. PMid:24778419 http://dx.doi.org/10.1084/jem.20131916

[57] Barsoum, I.B., et al. A mechanism of hypoxia-mediated escape from adaptive immunity in cancer cells. Cancer research. 2014; 74(3): 665-674. PMid:24336068 http://dx.doi.org/10.1158/0008-5472.CAN-13-0992

[58] Dousias, V., et al. Hypoxia-induced factor-1 $\alpha$ in endometrial carcinoma: a mini-review of current evidence. Histology and histopathology. 2012; 27(10): 1247-1253. PMid:22936443

[59] Liao, Y., et al. SHARP1 Suppresses Angiogenesis of Endometrial Cancer by Decreasing Hypoxia-Inducible Factor-1 $\alpha$ Level. PloS one. 2014; 9(6): e99907. PMid:24918449 http://dx.doi.org/10.1371/journal.pone.0099907 
[60] Kuiper, C., et al. Low ascorbate levels are associated with increased hypoxia-inducible factor-1 activity and an aggressive tumor phenotype in endometrial cancer. Cancer research. 2010; 70(14): 5749-5758. PMid:20570889

http://dx.doi.org/10.1158/0008-5472.CAN-10-0263

[61] De Pergola, G. and F. Silvestris, Obesity as a major risk factor for cancer. Journal of obesity. 2013. 2013 ID 291546.

[62] Roberts, D.L., C. Dive, and A.G. Renehan. Biological mechanisms linking obesity and cancer risk: new perspectives. Annual review of medicine. 2010; 61: 301-316. PMid:19824817 http://dx.doi.org/10.1146/annurev.med.080708.082713

[63] Koda, M., et al. Expression of the obesity hormone leptin and its receptor correlates with hypoxia-inducible factor-1 $\alpha$ in human colorectal cancer. Annals of oncology. 2007; 18(suppl 6): vi116-vi119. PMid:17591803 http://dx.doi.org/10.1093/annonc/mdm238

[64] Philips GK, A.M. Therapeutic uses of anti-PD-1 and anti-PD-L1 antibodies. Int Immunol. 2014. pii: dxu095. [Epub ahead of print]. PMid:25323844

[65] Li, Y., et al. Contribution of PD-L1 to oncogenesis of lymphoma and its RNAi-based targeting therapy. Leukemia \& lymphoma. 2012; 53(10): 2015-2023. PMid:22462616 http://dx.doi.org/10.3109/10428194.2012.673228

[66] Iwamura, K., et al. siRNA-mediated silencing of PD-1 ligands enhances tumor-specific human T-cell effector functions. Gene therapy. 2011; 19(10): 959-966. PMid:22113316 http://dx.doi.org/10.1038/gt.2011.185

[67] Borkner, L., et al. RNA interference targeting programmed death receptor-1 improves immune functions of tumor-specific T cells. Cancer immunology, immunotherapy. 2010; 59(8): 1173-1183. PMid:20349059 http://dx.doi.org/10.1007/s00262-010-0842-0

[68] Pen, J., et al. Interference with PD-L1/PD-1 co-stimulation during antigen presentation enhances the multifunctionality of antigen-specific T cells. Gene therapy. 2014; 21(3): 262-271. PMid:24401835 http://dx.doi.org/10.1038/gt.2013.80

[69] Song, M.-Y., et al. Enhancement of vaccine-induced primary and memory CD8+ t-cell responses by soluble PD-1. Journal of Immunotherapy. 2011; 34(3): 297-306. PMid:21389868 http://dx.doi.org/10.1097/CJI.0b013e318210ed0e

[70] Qiu, H., et al. Regulating immunity and inhibiting tumor growth by the recombinant peptide sPD-1-CH50. Anticancer research. 2009; 29(12): 5089-5094. PMid:20044621

[71] Xiao, H., et al. Soluble PD-1 facilitates 4-1BBL-triggered antitumor immunity against murine H22 hepatocarcinoma in vivo. Clinical Cancer Research. 2007; 13(6): 1823-1830. PMid:17325342 http://dx.doi.org/10.1158/1078-0432.CCR-06-2154

[72] HE, L., et al. Blockade of B7-H1 with sPD-1 improves immunity against murine hepatocarcinoma. Anticancer research. 2005; 25(5): 3309-3313. PMid:16101143

[73] Galaal, K., et al. Adjuvant chemotherapy for advanced endometrial cancer. Cochrane Database Syst Rev. 2014 May 15; 5: CD010681. doi: 10.1002/14651858.CD010681. http://dx.doi.org/10.1002/14651858.CD010681

[74] Dellinger, T.H., et al. Role of canonical Wnt signaling in endometrial carcinogenesis. Expert Rev Anticancer Ther. 2012; 12(1): 51-62. PMid:22149432 http://dx.doi.org/10.1586/era.11.194

[75] Chen, J. Multiple signal pathways in obesity-associated skin cancer. Toxicol Appl Pharmacol. 2010; 247(2): 166 ; author reply 167. PMid:20570690 http://dx.doi.org/10.1016/j.taap.2010.05.020

[76] Chen, J. and N.A. McMillan. Molecular basis of pathogenesis, prognosis and therapy in chronic lymphocytic leukaemia. Cancer Biol Ther. 2008; 7(2): 174-9. PMid:18059180 http://dx.doi.org/10.4161/cbt.7.2.5262

[77] Chen, J., et al. Activation of PI3K/Akt/MTOR Pathway and Dual Inhibitors of PI3K and MTOR in Endometrial Cancer. Curr Med Chem. 2014; 21(26): 3070-80. PMid:24735369 http://dx.doi.org/10.2174/0929867321666140414095605

[78] Chen, J., et al. Future of RNAi-based therapies for human papillomavirus-associated cervical cancer. 2007; 2 (6): $587-595$.

[79] Chen, J., N. McMillan, and W. Gu. Intra-tumor injection of lentiviral-vector delivered shRNA targeting human papillomavirus E6 and E7 oncogenes reduces tumor growth in a xenograft cervical cancer model in mice. Journal of Solid Tumors. 2012; 2(4): 4. http://dx.doi.org/10.5430/jst.v2n4p4

[80] Chen, J., et al. Insulin decreases therapeutic efficacy in colon cancer cell line HT29 via the activation of the PI3K/Akt pathway. Current drug discovery technologies. 2011; 8(2): 119-125. PMid:21513489 http://dx.doi.org/10.2174/157016311795563820

[81] Chen, J., et al. Insulin caused drug resistance to oxaliplatin in colon cancer cell line HT29. Journal of gastrointestinal oncology. 2011; 2(1): 27. PMid:22811824

[82] Davies, H., et al. Mutations of the BRAF gene in human cancer. Nature. 2002; 417(6892): 949-954. PMid:12068308 http://dx.doi.org/10.1038/nature00766

[83] Gonzalez-Rodilla, I., et al. Expression of the apoptosis-related genes Bcl-2 and p53 in clinical samples from endometrial carcinoma patients. Anticancer research. 2011;31(12): 4191-4193. PMid:22199279

[84] Rouette, A., et al. Cisplatin increases B-cell-lymphoma-2 expression via activation of protein kinase C and Akt 2 in endometrial cancer cells. International Journal of Cancer. 2012; 130(8): 1755-1767. PMid:21618512 http://dx.doi.org/10.1002/ijc.26183

[85] Weigelt, B., et al. PI3K pathway dependencies in endometrioid endometrial cancer cell lines. Clinical Cancer Research. 2013; 19(13): 3533-44. PMid:23674493 http://dx.doi.org/10.1158/1078-0432.CCR-12-3815 